\title{
Giant head neurofibroma
}

Figure Imaging of giant head neurofibroma
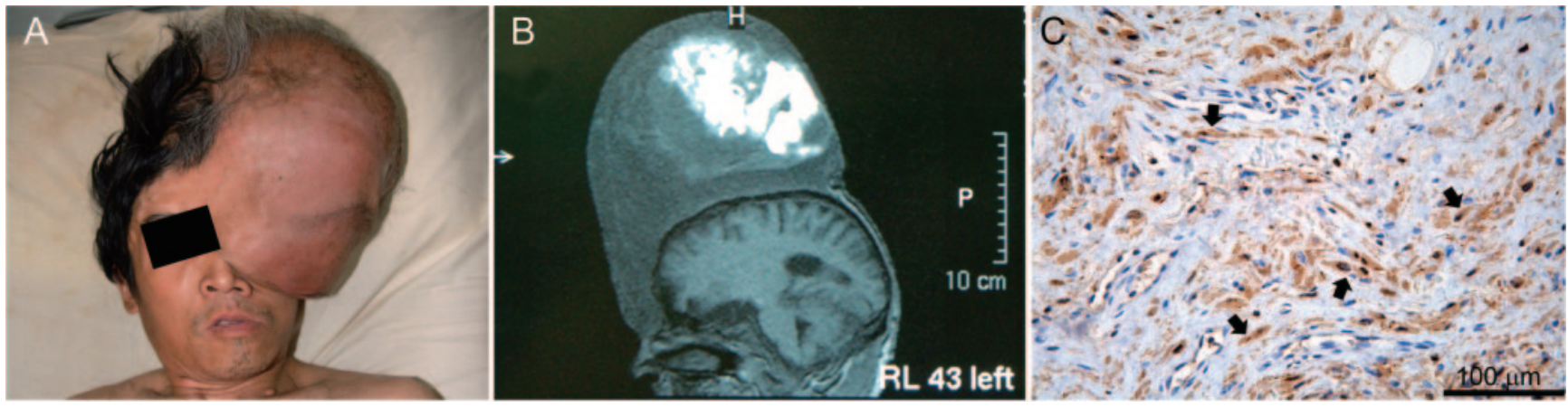

(A) Image of the giant head neurofibroma. (B) MRI demonstrated hyperintense signal lesion in the upper part of the mass and mild hypointense signal in the other area on T1-weighted image. (C) Histologic examination revealed a neurofibroma with blood vessel hyperplasia and extensive invasiveness, containing spindle, S100-positive tumor cells (arrows).

A 42-year-old man presented with a tense, tender 24-cm cranial lump in the left face and frontal-temporalparietal region (figure, A and B). Slow growth and limited local medical resources delayed presentation for care. Firm subcutaneous nodules were observed in other locations. A diagnosis of neurofibromatosis type I-like syndrome was made ${ }^{1}$; confirmatory genetic testing was not performed. The 5 -kg tumor was completely excised surgically, including an intracranial portion that grew through an orbital-frontal cranial defect. Histologic examination ${ }^{2}$ revealed a neurofibroma (figure, C). After 4 years of follow-up, besides the removed left eye damaged by the tumor, he had a satisfactory recovery.

X. Zhang, MD, PhD, X. Mao, MD, PhD, W. Zhang, MD, PhD, J. Zhang, MD, PhD, W. Cao, MD, PhD, Shaanxi, PR China

Author contributions: Xiang Zhang: design of the study, statistical analysis, and writing. Xinggang Mao: analysis of the data. Wei Zhang: drafting the manuscript. Jianning Zhang: revising the manuscript. Weidong Cao: interpretation of the data.

Disclosure: The authors report no disclosures.

Correspondence \& reprint requests to Dr. Xiang Zhang: xzhang@fmmu.edu.cn

1. Messiaen L, Yao S, Brems H, et al. Clinical and mutational spectrum of neurofibromatosis type 1-like syndrome. JAMA 2009;302:2111-2118.

2. Jouhilahti EM, Peltonen S, Heape AM, Peltonen J. The pathoetiology of neurofibromatosis 1. Am J Pathol 2011;178:19321939. 


\section{Neurology}

Giant head neurofibroma

X. Zhang, X. Mao, W. Zhang, et al. Neurology 2012;78;71

DOI 10.1212/WNL.0b013e31823ed117

This information is current as of December 26, 2011

\section{Updated Information \&} Services

References

Subspecialty Collections

Permissions \& Licensing

Reprints including high resolution figures, can be found at: http://n.neurology.org/content/78/1/71.full

This article cites 2 articles, 0 of which you can access for free at: http://n.neurology.org/content/78/1/71.full\#ref-list-1

This article, along with others on similar topics, appears in the following collection(s):

MRI

http://n.neurology.org/cgi/collection/mri

Nerve tumor

http://n.neurology.org/cgi/collection/nerve_tumor

Surgical therapy-tumor

http://n.neurology.org/cgi/collection/surgical_therapytumor

Information about reproducing this article in parts (figures,tables) or in its entirety can be found online at:

http://www.neurology.org/about/about_the_journal\#permissions

Information about ordering reprints can be found online:

http://n.neurology.org/subscribers/advertise

Neurology ${ }^{\circledR}$ is the official journal of the American Academy of Neurology. Published continuously since 1951, it is now a weekly with 48 issues per year. Copyright Copyright (C 2012 by AAN Enterprises, Inc.. All rights reserved. Print ISSN: 0028-3878. Online ISSN: 1526-632X.

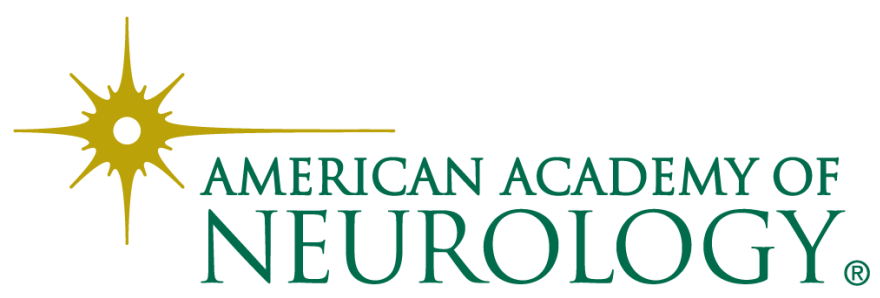

